\title{
Wojnowicia graminis on Gramineae
}

\author{
KAIHO MÄKELÄ
}

\begin{abstract}
MÄKELÄ, K. 1979: Wojnowicia graminis on Gramineae. - Karstenia 19: 54-57.
The material consisted of 1035 samples of ripening cereals gathered from 119 localities in southern Finland and 32 samples of Agropyron repens. Wojnowicia graminis (Mc Alp.) Sacc. \& D. Sacc. (Deuteromycotina: Sphaeropsidales) was found in 32 cereal samples from 22 localities. The fungus was fairly common on Triticum aestivum (winter wheat), infrequent on Secale cereale and Hordeum vulgare, and absent from A vena sativa. It was recorded on six samples of Agropyron repens from six localities.

$W$. graminis causes symptoms resembling the take-all caused by Gaeumannomyces graminis (Sacc.) Arx \& Olivier. In fields in southern Finland, W. graminis appears to be rather rare, sparse and of negligible pathogenic importance.
\end{abstract}

Kaiho Mäkelä, Agricultural Research Centre, Institute of Plant Pathology, SF-01300 Vantaa 30, Finland

Wojnowicia graminis (Mc Alp.) Sacc. \& D. Sacc. in Saccardo, Syll. Fung. 18: 367. 1906. - Syn. Hendersonia graminis Mc Alpina, Dept. Agric. Victoria Bull. 9: 9. 1904.

According to Sprague (1950), Hendersonia crastophila Sacc. also appears to be the same species.

Wojnowicia Saccardo (Syll. Fung. 10: 328. 1892) is a genus of Sphaeropsidales. Altogether it comprises about five species (Ainsworth et al. 1971).

$W$. graminis is widely distributed in Europe, having been reported from France, the Netherlands (Broadfoot 1933, Sprague 1935), Great Britain (Anomymous 1935), Germany (Fuchs 1935), Bulgaria (Todorova 1957), Romania (Săvulescu \& Puscasu 1967), Byelorussia, the Baltic Republics, West Unkraine and North Caucasus (Karshunova 1968), and is common in North America (Mc Kinney \& Johnson 1921, Broadfoot 1933, Sprague 1935, 1950), and Australia (Mc Alpine 1904, Pittman 1937). The fungus is new to Finland.

$W$. graminis is found on cereal hosts, including Avena sativa, Hordeum vulgare, Secale cereale and Triticum aestivum, and on other grass species as well, e.g. Agropyron repens (Sprague 1935, 1950). The fungus is common, particularly on wheat, frequently being associated with foot rot and root rot diseases in cereals. It is usually considered only a secondary pathogen (Sprague 1935, Pittman 1937, Săvulescu \& Puscasu 1967). On the other hand, $W$. graminis is regarded as a source of root rot in wheat (Mc Kinney \& Johnson 1921).

\section{Material and methods}

The material consists of ripening cereal samples gathered in farmers' fields in south-western and southern Finland during the years 1975-1977.

Of the 1035 cereal samples examined, 611 belonged to Triticum aestivum (362 spring wheat and 249 winter wheat), 77 to Secale cereale, 242 to Hordeum vulgare and 105 to Avena sativa. The samples were gathered from 119 localities. In addition, the material collected in 1975 included 32 samples of Agropyron repens, which is a common weed in cereal fields.

The bases and roots of the cereal samples were kept on moist blotting-paper in Petri dishes under laboratory conditions $\left(+18-22^{\circ} \mathrm{C}\right)$ for two weeks and thereafter at about $+10^{\circ} \mathrm{C}$ for two weeks. The fungi were studied with a microscope and photographed. The films are preserved by the author.

\section{Results and discussion}

$W$. graminis was found to occur rather infrequently in the southern parts of the country (Fig. 1). On an average, it was recorded in $3.1 \%$ of the fields $(n=1035)$ and at $17.6 \%$ of the localities $(n=119)$ studied (Table 1). The fungus was much commoner on winter wheat, than on other cereals, occuring on an average in $7.2 \%$ of the fields $(n=249)$ studied. On 


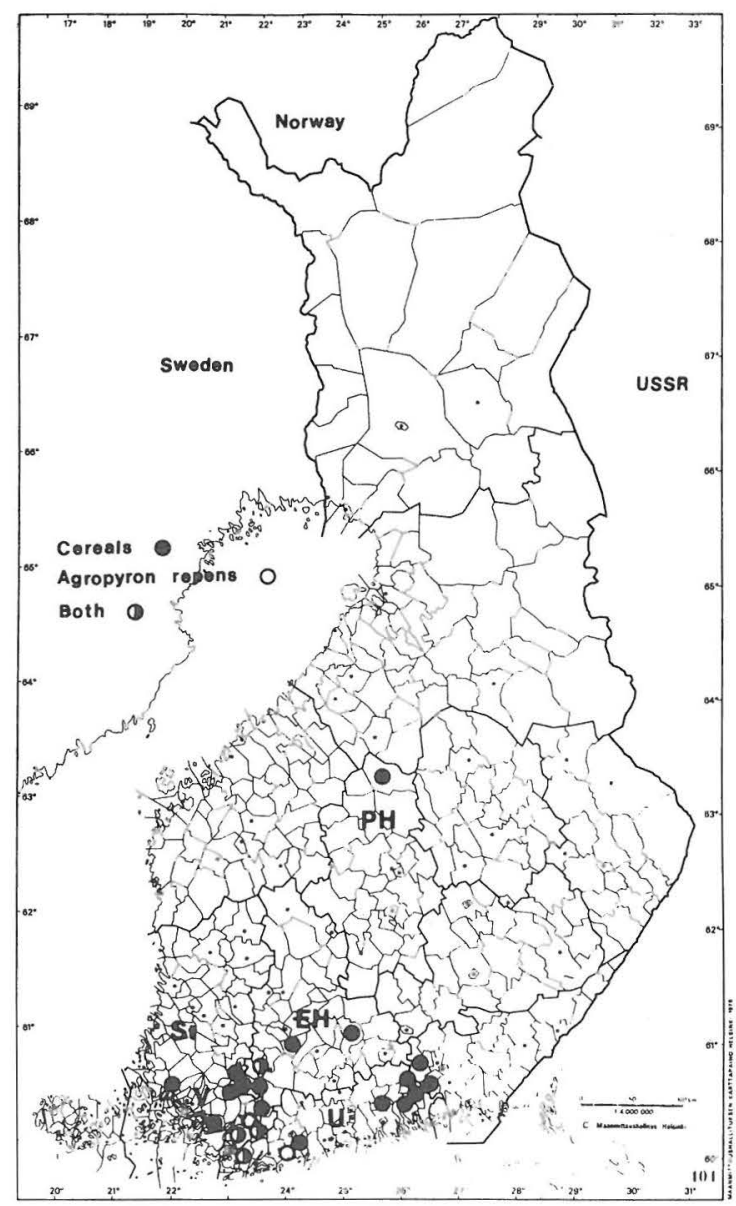

Fig. 1. The records of Wojnowicia graminis on Gramineae in Finland.

oats the fungus was not observed at all. It was found on Agropyron repens in $14.3 \%$ of the fields $(n=42)$ studied in the autumn of 1975. W. graminis was always determined by means of the pycnidia and pycnospores. The fungus has been observed on the same hosts elsewhere (Sprague 1935, 1950), in particular on wheat (Mc Kinney \& Johnson 1921, Broadfoot 1933, Sprague 1935, Pittmann 1937, Korshunova 1968).

Wojnowicia graminis causes root rot in the host plants and produces partly superficial, dark brown to black spots and streaks on the basal parts of the culms (Figs. 2-3). The pycnidia of the fungus were found on the lower leaf sheaths both above and below the soil line. Usually they were found on the inner side of the sheath, later breaking through the sheath (Fig. 3). The injuries resemble the take-all
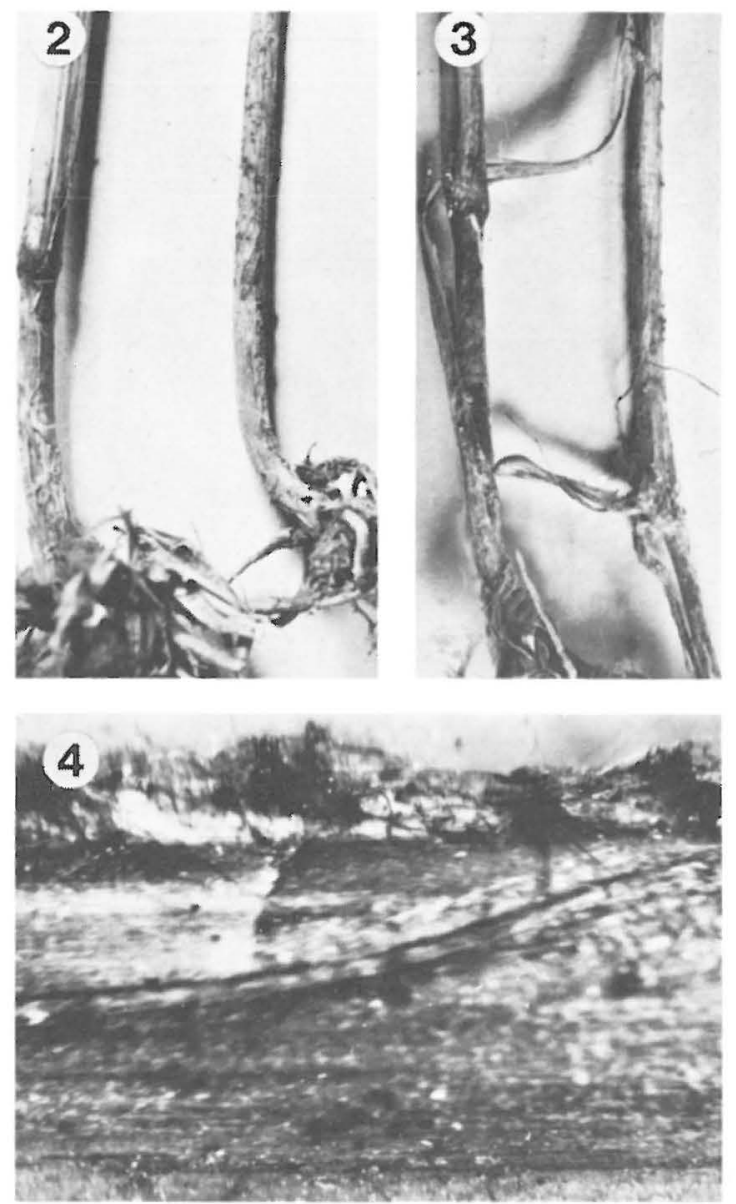

Figs. 2-4. Culms of Triticum aestivum (winter wheat) infected by Wojnowicia graminis. Pycnidia of the fungus are protruding through the leaf sheath. -2 : V. Mietoinen, 16.VIII.1977 Kössi. $\times$ 1. - 3: U. Siuntio, 8.VIII.1977 Mäkelä. $\times$ 1. -4 : V. Mietoinen, 19.VIII.1975 Mäkelä. $\times$ 10 .

caused by Gaeumannomyces graminis (Sacc.) Arx \& Olivier (Mc Kinney \& Johnson 1921, Todorova 1957). Moreover $W$. graminis is often so closely associated with G. graminis (Broadfoot 1933, Săvulescu \& Puscasu 1967), Cercosporella herpotrichoides (Sprague 1935, 1950) and several other fungi (Korshunova 1968) that very few specific symptoms are recognizable. The pycnidia of $W$. graminis are immersed, globose, rostrate to corniform. They generally have abundant long, dense, brown hairs around the ostiole, but some are glabrous, without hairs (Fig. 9). Brown, ramifying mycelium is sometimes seen around the pycnidium (Figs. 5, 7, 10). 

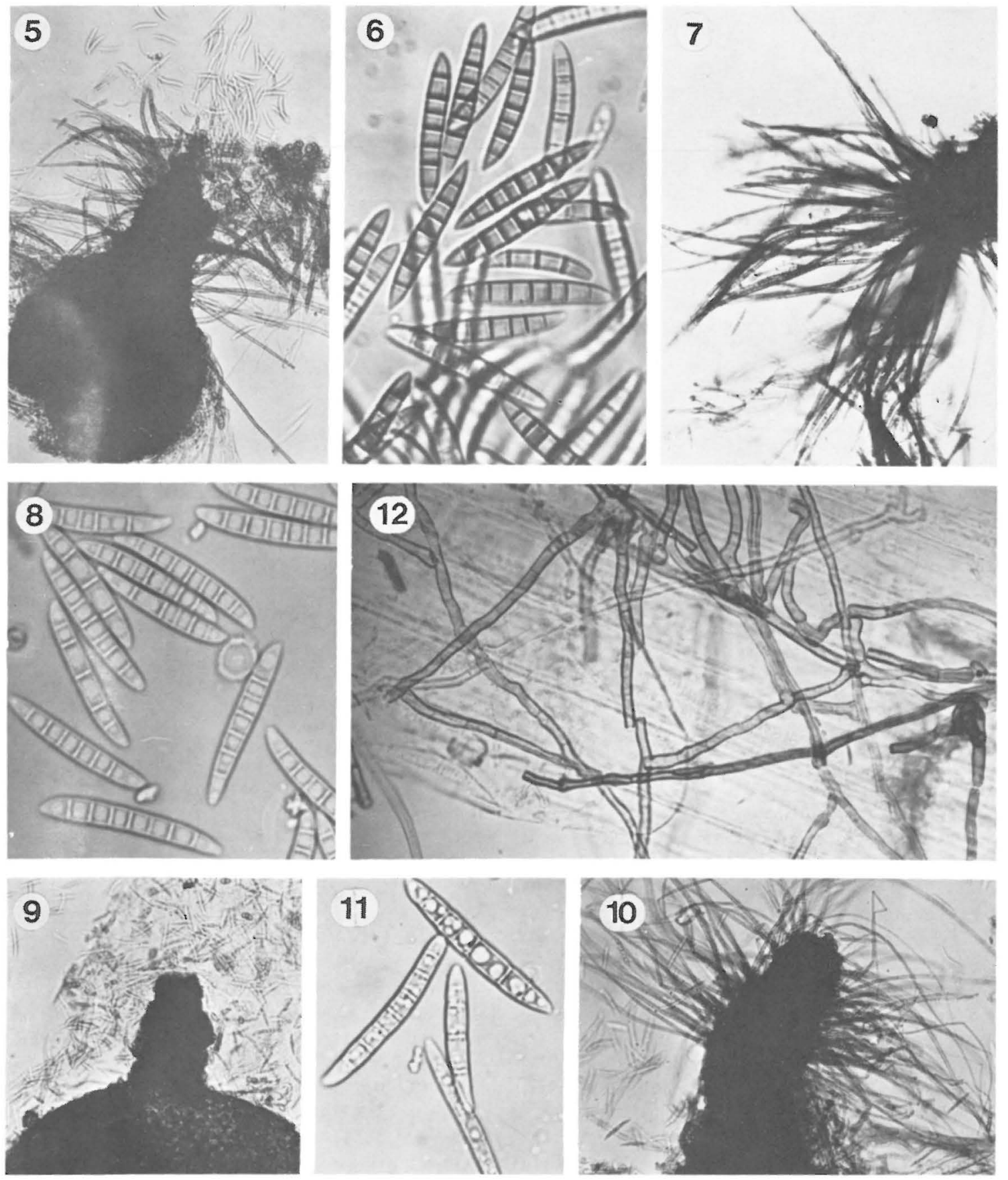

Figs. 5-12. Pycnidia and conidia of Wojnowicia graminis. - 5-9: On Triticum aestivum (5 spring wheat, 6-9 winter wheat). - 10-11: On Agropyron repens. - 12: Hyphae of the fungus under a leaf sheath on Hordeum vulgare.

Material: - 5: V. Marttila, 9.IX.1976 Kurtto. - 6: V. Perniö, 19.VIII.1976 Mäkelä. - 7-8: V. Kisko, 12.VIII.1975 Koponen. - 9: EH. Somero, 4.VIII.1975 Mäkelä. - 10-11: EH. Jokioinen, 19.VIII.1975 Mäkelä. - 12: V. Sauvo, 16. VIII.1977 Parikka. Magnifications: $-5,7,9: \times 100 .-10: \times 150 .-6,8,11,12: \times 750$. 
Table 1. Occurrence of Wojnowicia graminis on various hosts in the fields studied in 1975-1977

\begin{tabular}{lcc}
\hline Hosts & $\begin{array}{c}\text { No. of } \\
\text { samples }\end{array}$ & $\begin{array}{c}\text { Samples } \\
\text { infected } \\
\%\end{array}$ \\
\hline Agropyron repens & 42 & 14.3 \\
Avena sativa & 105 & 0.0 \\
Hordeum vulgare & 242 & 1.7 \\
Scale cereale & 77 & 2.6 \\
Triticum aestivum & 611 & 4.3 \\
$\quad$ (Spring wheat) & $(362)$ & $(2.2)$ \\
(Winter wheat) & $(249)$ & $(7.2)$ \\
Cereals total & 1035 & 3.1 \\
& &
\end{tabular}

The conidia are pale brown in mass, yellow-brown when single, falcate, apically almost corniform, usually 7 -septate (Figs. 6, 8, 11). The pycnidia are (394-) $588(-764) \mu \mathrm{m}$ long, with the neck (285-) $373(-462) \mu \mathrm{m}$ wide and (202-) $280(-326) \mu \mathrm{m}$ long. The largest pycnidia were found on the samples of winter wheat. The conidia $(n=80)$ are $(28.7-)$ 35.2 (-39.6) $\mu \mathrm{m}$ long, (3.3-) $3.4(-4.6) \mu \mathrm{m}$ wide, (5-) 7.7 (-9) -septate. The variation between the different cereals was not significant. The conidia on Agropyron repens were somewhat larger $(n=40)$, (27.6-) $37.2(-63.2) \mu \mathrm{m}$ long, $(2.3-) 4.2(-7.1) \mu \mathrm{m}$ wide (4-) $6.8(-9)$-septate (cf. Sprague 1950). The same difference has been observed in previous studies (Saccardo 1906, Sprague 1935).

The author cannot agree with Sprague's (1950) opinion that Hendersonia crastophila and Wojnowicia graminis may be the same fungus (cf. Mäkelä 1977).

\section{Specimens examined:}

On Agropyron repens:

V: Kisko; Muurla; Perniö; Tenhola, 12.VIII.1975 Koponen. - U: Inkoo, 12.VIII.1975 Koponen. - EH: Jokioinen, 19.VIII.1975 Mäkelä.

On Hordeum vulgare:

V: Sauvo, 16.VIII.1977 Parikka. - EH: Lammi, 17.IX.1977 Mäkelä. - PH: Pihtipudas, 24.VI.1976 Kössi. On Secale cereale:

U: Artjärvi, 17.VIII.1976 Kurtto. - EH: Iitti, 14.VIII.1976 Kurtto.
On Triticum aestivum (spring wheat):

V: Kiikala, 22.IX.1977 Kössi; Marttila, 9.IX.1976 Kurtto; Perniö, 19.VIII.1976 Mäkelä. - U: Lapinjärvi; Liljendal, 24.VIII.1977 Mäkelä; Siuntio, 8.IX.1977 Mäkelä. - EH: Iitti, 22.VIII.1977 Kurtto; Jokioinen, 19.VIII.1975 Mäkelä. On Triticum aestivum (winter wheat):

V: Kisko, 12.VIII.1975 Koponen; Koski, 14.X.1975 Kurtto; Mellilä, 4.VIII.1975 Mäkelä; Mietoinen, 19.VIII.1975 Mäkelä, 16.VIII.1977 Kössi. - U: Askola (2 specimens), 17.VIII.1976 Kurtto; Elimäki (2 exx.), 24.VIII.1977 Mäkelä; Lapinjärvi, 24.VIII.1977 Mäkelä; Perniö (2 exx.), 19.VIII.1976 Mäkelä. - EH: Iitti, 14.VIII.1976 Kurtto; Jokioinen, 4.VIII.1975 Mäkelä; Kalvola, 3.IX.1977 Mäkelä; Somero (2 exx.), 19.VIII.1976 Mäkelä.

\section{References}

Ainsworth, G.C., James, P.W. \& Hawksworth, D.L. 1971: Dictionary of the fungi. $-663 \mathrm{pp}$. Kew.

Anonymous 1935: England and Wales: new and interesting phytopathological records for the year 1934. - Int. Bull. Pl. Prot. 9(3): 53-54.

Broadfoot, W.C. 1933: On the pathogenicity of Wojnowicia graminis. - Phytopathology 23: $1001-1002$.

Fuchs, W.H. 1935: Die Getreidefusskrankheit im Gebiet von Halle. - Kühn-Archiv 39: 115-120.

Korshunova, A.F. 1968: Kornevye gnili pshenits. [Roots rots of wheat.] - Zashch. Rast. Mosk. 13: 12-14. (Ref.: Rev. Appl. Mycol. 48: 120.)

Mäkelä, K. 1977: Hendersonia, Phaeoseptoria and Stagonospora on Gramineae in Finland. - Ann. Agric. Fenniae 16: 238-255.

Mc Alpine, D. 1904: Take-all and whiteheads in wheat. J. Dep. Agric. Victoria 2: 410-426. (Reprinted as Dept. Agr. Victoria Bull. 9: 1-20.)

Mc Kinney, H.H. \& Johnson, A.G. 1921: Wojnowicia graminis (Mc Alp.) Sacc. and D. Sacc. on wheat in the United States. - Phytopathology 11: 505-506.

Pittman, H.A. 1937: Take-all and similar diseases of wheat and how to control them. - J. Dep. Agric. W. Austr., Ser. 2, 14: 103-112.

Saccardo, P.A. 1906: Sylloge Fungorum. 18. - 838 pp. Patavii.

Sǎvulescu, A. \& Puscasu, A. 1967: Einige Pilze, welche die Fusskrankheit des Getreides in Rumänien verursachen. - Sydowia 21: 188-199.

Sprague, R. 1935: Wojnowicia graminis as a very weak secondary parasite of winter cereal crops. Phytopathology 25: 405-415.

-"- 1950: Diseases of cereals and grasses in North America. - $538 \mathrm{pp}$. New York.

Todorova, V. 1957: [Foot rot and root rot of cereals.] Bull. Plant Prot., Sofia 6(4): 15-28. (Ref.: Rev. Appl. Mycol. 37: 527.) 